\title{
Responses of photosynthesis to high temperatures in oak saplings assessed by chlorophyll-a fluorescence: inter-specific diversity and temperature-induced plasticity
}

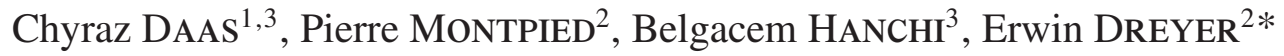 \\ ${ }^{1}$ INRGREF, Laboratoire d'Écophysiologie Végétale, Tunis, Tunisia \\ ${ }^{2}$ INRA, Nancy-Université, UMR 1137 «Écologie et écophysiologie forestières », 54280 Champenoux, France \\ ${ }^{3}$ Département des Sciences biologiques végétales, Faculté des sciences de Tunis Université de Tunis El Manar
}

(Received 8 August 2007; accepted 8 November 2007)

\begin{abstract}
-
- The sensitivity of photosynthesis to high temperature was investigated in greenhouse-grown saplings of three Mediterranean (Quercus canariensis Willd., $Q$. coccifera L. and $Q$. suber L.) and two temperate European oak species ( $Q$. robur L. and $Q$. petraea Matt. Liebl.). The sensitivity to high temperature was inferred from $F_{0}$ T curves producing the critical temperature $\left(T_{c}\right)$ at which a rapid rise in ground chlorophyll a fluorescence $\left(F_{0}\right)$ occurs. $T_{c}$ is known to acclimate to moderately increased ambient temperature by displaying significant increases.

- We first checked whether acclimation of $T_{c}$ was paralleled by an increase in optimal temperature for light driven electron flux $\left(T_{o p t}\right.$, ), recorded by measuring quantum yield of photochemistry under saturating $\mathrm{CO}_{2}$ and moderate irradiance. Saplings of $Q$. suber and $Q$. canariensis were submitted to four, five days long ambient temperature steps $\left(15,25,35\right.$ and $15{ }^{\circ} \mathrm{C}$ again). $T_{c}$ was usually largely above $45{ }^{\circ} \mathrm{C}$ while $T_{\text {opt }}$ was around $30-35{ }^{\circ} \mathrm{C}$. Both increased with ambient temperature in the two species, and decreased again when temperature returned to the initial values. This recovery was nevertheless not complete after a week at $15^{\circ} \mathrm{C}$.

- A second experiment tested whether the plasticity of $T_{c}$ was of the same extent in the five species. A significant increase of $T_{c}$ followed by a decrease was detected in all species. Only small inter-specific differences were detected in $T_{c}$, and temperature induced plasticity was similar in the different species: $T_{c}$ increased by about $4-5{ }^{\circ} \mathrm{C}$ while ambient temperature was increased from 15 to $35^{\circ} \mathrm{C}$. Mediterranean and European oaks did not differ in this respect.

- This result does not support the hypothesis that oak species from warmer regions would display a larger plasticity of $T_{c}$ in response to increasing temperatures.

photochemistry / quantum yield / optimal temperature / Quercus suber / Quercus canariensis / Quercus coccifera / Quercus robur / Quercus petraea

Résumé - Thermotolérance de la photosynthèse de chênes européens mesurée par la fluorescence de la chlorophylle : diversité interspécifique et plasticité induite par l'acclimatation thermique.

- La sensibilité de la photosynthèse à des températures élevées a été étudiée chez cinq espèces de chênes : trois méditerranéennes (Quercus canariensis Willd., $Q$. coccifera L. et $Q$. suber L.) et deux tempérées $(Q$. robur L. et $Q$. petraea Matt. Liebl.). La sensibilité aux fortes températures était estimée suivant la procédure des courbes $F_{0} T$ par la température critique $\left(T_{c}\right)$ au dessus de la quelle la fluorescence de base de la chlorophylle $\left(F_{0}\right)$ augmente rapidement. $T_{c}$ présente une forte capacité d'acclimatation et augmente sensiblement après une élévation modérée de la température ambiante.

- Dans une première expérimentation nous avons vérifié si une augmentation de $T_{c}$ s'accompagnait d'une augmentation de la température optimale du transfert d'électrons durant la photochimie $\left(T_{o p t}\right)$, estimée par mesure du rendement quantique de la photochimie sous $\mathrm{CO}_{2}$ saturant sous éclairement modéré. Les jeunes plants de $Q$. suber et $Q$. canariensis ont été soumis à quatre températures ambiantes $\left(15^{\circ} \mathrm{C}, 25^{\circ} \mathrm{C}, 35^{\circ} \mathrm{C}\right.$ et de nouveau $\left.15{ }^{\circ} \mathrm{C}\right)$ pendant cinq jours. $T_{c}$ atteignait des valeurs supérieures à $45^{\circ} \mathrm{C}$ alors que $T_{o p t}$ était aux alentours de $30-35^{\circ} \mathrm{C}$. Chez les deux espèces, ces paramètres ont augmenté avec la température ambiante et à nouveau diminué lors du retour à la température initiale. Nous avons conclu que le changement de la thermostabilité de la photochimie du PSII s'est accompagné d'un changement de la température optimale du transfert d'électrons photosynthétiques.

- Dans une deuxième expérimentation nous avons comparé $T_{c}$ sur cinq espèces de chêne soumises à la même séquence climatique que précédemment. $T_{c}$ et sa plasticité différaient très peu entre espèces : $T_{c}$ a augmenté de $4-5^{\circ} \mathrm{C}$ alors que la température ambiante passait de 15 à $35^{\circ} \mathrm{C}$. Les cinq espèces de chênes ne présentaient pas de différences marquées ni de valeur absolue de $T_{c}$, ni de plasticité de ce paramètre.

- Ces résultats ne confirment pas l'hypothèse que les espèces méditerranéennes de chêne présenteraient des valeurs plus élevées de $T_{c}$, ou une plus forte plasticité de ce paramètre que les espèces de régions tempérées.
\end{abstract}

fluorescence de la chlorophylle / température optimale / photochimie / Quercus suber / Quercus canariensis / Quercus robur / Quercus petraea / Quercus coccifera

\footnotetext{
* Corresponding author: dreyer@nancy.inra.fr 


\section{INTRODUCTION}

Mediterranean climate is well known for long lasting periods of drought during summer, with large irradiance loads and temperature maxima that may reach 40 to $45^{\circ} \mathrm{C}$. Such conditions impose strong stresses on leaves of tree species like oaks (Rennenberg et al., 2006). High temperatures above $40{ }^{\circ} \mathrm{C}$, may under circumstances induce leaf necroses and yellowing (Schreiber and Berry, 1977). Among cellular functions, photosynthesis is frequently regarded as one of the most sensitive to high temperatures (Berry and Björkman, 1980). The reversible impact of moderately high temperature (i.e., 35$40{ }^{\circ} \mathrm{C}$ ) on photosynthetic functions includes rubisco deactivation (Salvucci and Crafts-Brandner, 2004), and inhibition of electron transport capacity but no direct damage to photosystem II (PS II) (see Sharkey, 2005, for an overview). Such reversible effects may be quantified by the temperature inducing a $15 \%$ reduction of $F_{v} / F_{m}$, the dark-acclimated quantum yield of photochemistry (Epron, 1997b). Higher temperatures (above $40{ }^{\circ} \mathrm{C}$ ) may involve direct damage to PSII photochemistry: PSII proteins may be denaturated and thylakoid membrane fluidity may increase to very high levels when temperature reaches critical values (Ducruet et al., 2007; Yordanov, 1992). This critical temperature for PSII functions may be assessed using chlorophyll a fluorescence records and by detecting the leaf temperature at the thermal breakpoint of ground level chlorophyll a fluorescence recorded under darkness $\left(F_{0}\right)$, called critical temperature $T_{c}$, (Bilger et al., 1984; Ducruet et al., 2007; Terzaghi et al., 1989). Increased $F_{0}$ denotes an inactivation of PS II reaction centres due to thylakoid instability and complex changes in PS II (Cajanek et al., 1998; Ducruet et al., 2007). This technique has been used to assess the heat sensitivity of photosynthesis in a number of species (Knight and Ackerly, 2002).

$T_{c}$ recorded on individuals at a common acclimation temperature displayed only little inter-specific variability in a range of species including Mediterranean and mid European tree species (Froux et al., 2004; Ghouil et al., 2003) or coastal vs desert species in California (Knight and Ackerly, 2002). $T_{c}$ was usually around $45-50{ }^{\circ} \mathrm{C}$ for saplings grown under $20^{\circ} \mathrm{C}$ ambient temperature.

Direct interspecific comparisons are made difficult by the fact that $T_{c}$ is a highly plastic trait (see Ducruet et al., 2007, for a synthesis). $T_{c}$ can be influenced by a series of environmental parameters like ambient temperature (Dreyer et al., 2001; Havaux, 1993; Robakowski et al., 2002), water availability (Epron, 1997a; Havaux, 1992; Ladjal et al., 2000) and plant growth regulators like ABA (Havaux, 1992; Ivanov et al., 1992). $T_{c}$ varies largely with season, in parallel to ambient temperatures, and increases during summer and decreases during autumn (Froux et al., 2004; Hüve et al., 2006). Large increases of $T_{c}$ can be induced by increasing ambient temperatures over a few days as shown in silver fir (Robakowski et al., 2002). Similarly, a $10{ }^{\circ} \mathrm{C}$ shift of $T_{c}$ was observed in $Q$. suber when ambient temperature was increased from 10 to $40{ }^{\circ} \mathrm{C}$ (Ghouil et al., 2003).

Several studies showed that drought does also lead to an increase of thermostability of PSII. This was the case in $\mathrm{Ce}$ - drus atlantica (Epron, 1997a; Ladjal et al., 2000). In Q. suber, a $10{ }^{\circ} \mathrm{C}$ increase of $T_{c}$ was evidenced during the course of a severe drought that resulted in complete stomatal closure (Ghouil et al., 2003). The rate of increase of $T_{c}$ was rather high (close to $1{ }^{\circ} \mathrm{C}$ day $^{-1}$ ) during the cited experiments. Unfortunately, the reversibility after re-irrigation of such large increases was never documented. The degree of reversibility of $T_{c}$ acclimation would bring interesting information about the processes involved.

Changes of $T_{c}$ reflect acclimation processes in the PS II reaction centers. $T_{c}$ is much higher than the optimum temperature for light driven electron flux $\left(T_{o p t}\right)$ estimated from the temperature response of $\mathbf{J}_{\max }$, the maximal rate of electron flow derived from leaf photosynthesis models. $T_{o p t}$ is usually close to $35^{\circ} \mathrm{C}$ (Dreyer et al., 2001; Medlyn et al., 2002a). $T_{o p t}$ has been shown to acclimate to some extent to long term changes in ambient temperature (Berry and Björkman, 1980; Medlyn et al., 2002b; Yamori et al., 2005). It remains nevertheless to be demonstrated whether increases in $T_{c}$ are matched by increases of the thermal optimum of light driven electron flow $\left(T_{\text {opt }}\right)$ and whether the two parameters display similar levels of acclimation to a rise in ambient temperature.

Large scale inter-specific or genotypic comparisons of $T_{c}$ were only seldom conducted. The few available studies failed to reveal higher values in species from warmer environments (Knight and Ackerly, 2002). The open question are therefore: (i) whether genotypes or species from warm environments display larger values of $T_{c}$ under common conditions of moderate ambient temperatures, and (ii) whether they differ in the ability to acclimate to increasing ambient temperatures by enhanced values of $T_{c}$; in other words, whether they display a larger plasticity of $T_{c}$ than those from cooler environments.

The present study therefore aimed at:

(1) Checking whether an ambient temperature-induced increase in the critical temperature for photochemistry $\left(T_{c}\right)$ recorded in the dark was matched by a similar increase in the optimal temperature for light driven electron transport $\left(T_{o p t}\right) . T_{o p t}$ was estimated from the response to air temperature of actual quantum yield of photochemistry of attached leaves under moderate irradiance and high $\mathrm{CO}_{2}$.

(2) Checking whether the ability of $T_{c}$ to acclimate to moderately increasing temperatures, and the extent of this acclimation, was similar among oak species from different geographic areas (Mid-European vs. Mediterranean).

(3) Checking whether the return to initial lower temperatures resulted in a reversal of the observed increases of $T_{c}$, and $T_{o p t}$ and to quantify this reversibility in the same oak species.

To answer these questions, we used saplings from five oak species (three Mediterranean and two mid European ones) grown under common conditions in a greenhouse in Northeastern France. 


\section{MATERIALS AND METHODS}

\subsection{Plant material}

Acorns of cork oak (Q. suber L.), zeen oak (Q. canariensis Willd.) and kermes oak (Q. coccifera $\mathrm{L}$.) were collected in Northern-Tunisia between Tabarka and Ain Drahem, during autumn 2003 and germinated in a greenhouse at INRA Nancy during spring 2004. Acons of pedunculate $(Q$. robur L.) and sessile oak (Q. petraea Matt. Liebl.) were collected in the Domain Forest of Compiègne, Northern France during autumn 2003 and planted in the same greenhouse. Saplings were grown in $5 \mathrm{~L}$ pots on a peat/sand mixture $(1 / 2 \mathrm{v} / \mathrm{v})$ and fertilised with a slow release fertiliser Nutricot 100 (N/P/K, 13/13/13 + oligoelements). Irrigation was automated. The experiments were conducted during October 2004.

\subsection{Thermal preconditioning}

During the experiments, 10 potted saplings of each species were transferred to a climate chamber under a PPFD of $300 \mu \mathrm{mol} \mathrm{m} \mathrm{m}^{-2} \mathrm{~s}^{-1}$, $60 \%$ relative humidity and air temperature controlled at 15,25 , or $35^{\circ} \mathrm{C}$, with a $14 / 8 \mathrm{~h}$ day/night photoperiod. The potted saplings were kept during one week successively at each temperature and returned to $15^{\circ} \mathrm{C}$. Measurements were conducted after 5 to 7 days acclimation to each ambient temperature, on fully expanded mature leaves produced during Spring 2004.

\subsection{Maximal quantum yield of photochemistry $\left(\mathbf{F}_{v} / F_{m}\right)$ in leaves}

Chlorophyll a fluorescence was measured with a modulated fluorimeter (PAM 2000, Heinz Walz, Effeltrich, Germany) on attached leaves that had been dark-acclimated for $8 \mathrm{~h}$ prior to harvest $(n=6)$. Ground fluorescence $\left(F_{0}\right)$ was obtained with a low intensity modulated light $\left(600 \mathrm{~Hz}, 650 \mathrm{~nm}, \mathrm{PFD}<1 \mu \mathrm{mol} \mathrm{m} \mathrm{m}^{-2} \mathrm{~s}^{-1}\right)$. Maximal fluorescence $\left(F_{m}\right)$ was induced by a saturating flash (halogen lamp, $0.8 \mathrm{~s}$, $4500 \mu \mathrm{mol} \mathrm{m} \mathrm{m}^{-2} \mathrm{~s}^{-1}$ ). The ratio $F_{v} / F_{m}$ was used as an estimate of maximal quantum yield of photochemistry (Kitajima and Butler, 1975).

$$
\frac{F_{v}}{F_{m}}=\frac{F_{m}-F_{0}}{F_{m}}
$$

\subsection{Temperature optimum of light-driven electron flow}

The temperature optimum of light driven electron flow was assessed from the quantum yield of photochemistry $\left(\Delta F / F_{m}\right.$, Genty et al., 1989). Saplings were transferred from the climate chamber to the laboratory, and one leaf inserted into a gas exchange chamber ADC (ADC Bioscientific, Herts, UK). The chamber was illuminated with a halogen lamp and incident phtosynthetic photon flux density at leaf level (below the window) was set at $500 \mu \mathrm{mol} \mathrm{m} \mathrm{m}^{-2} \mathrm{~s}^{-1}$. The temperature in the chamber was controlled with water circulating in the aluminium body and through a water bath with temperature control. Leaf temperature was measured with a thermocouple at leaf contact, inserted through the bottom of the chamber, and recorded on a Campbell data recorder CR10X (Campbell Scientific, Logan, Utah, USA). Inflowing air was humidified and dew point temperature imposed through a home built water-trap to provide at least $50 \% \mathrm{RH}$ at the highest temperature. Inlet air was controlled at $1 \% \mathrm{O}_{2}$ and $1000 \mathrm{ppm} \mathrm{CO}_{2}$, to saturate photosynthesis, inhibit photorespiration and minimise the impact of changes in stomatal conductance on $\mathrm{CO}_{2}$ assimilation and consequently on electron transfer. Chlorophyll a fluorescence was recorded with a Mini PAM (Heinz Walz, Effeltrich, Germany) with the fiber optics installed above the leaf chamber at an angle of $45^{\circ} \mathrm{C}$ to avoid shading of fractions of leaf area. A saturating flash at maximal intensity was delivered every second minute to record $\Delta F / F_{m}$ as an estimator of the quantum yield of photochemistry. Under these conditions, changes in $\Delta F / F_{m}$ were considered to reflect changes in maximal electron flux rate. Temperature in the chamber was increased from 10 to $50{ }^{\circ} \mathrm{C}$ at a pace of $1{ }^{\circ} \mathrm{C} \mathrm{min}{ }^{-1}$ approx. The relationship between leaf temperature and $\Delta F / F_{m}$ was used to estimate the optimal temperature of electron transfer by fitting the following empirical model to the data (June et al., 2004):

$$
J_{T L}=J_{T o p t} \times \mathrm{e}^{-\left(\frac{T_{L}-T_{o p t}}{\Omega}\right)^{2}}
$$

with: $J_{T L}$ : quantum yield at actual leaf temperature; $J_{\text {Topt }}$ : maximal quantum yield at optimal leaf temperature; $T_{L}$ : actual leaf temperature;

$T_{\text {opt }}$ : optimal leaf temperature; $\Omega$ : curvature factor.

\subsection{Critical temperature for thermal stability of PSII}

Photosystem II thermostability was estimated from critical temperature inducing a steep rise in ground fluorescence $\left(T_{c}\right)$ (Bilger et al., 1984; Ivanov et al., 1992) as described in Robakowski et al., 2002. A leaf disk was punched out and inserted into a device that exposes the disk to a target temperature $\left( \pm 0.1{ }^{\circ} \mathrm{C}\right)$ that gradually increases from 20 to $60^{\circ} \mathrm{C}$ at a constant rate of $1{ }^{\circ} \mathrm{C} \mathrm{min}{ }^{-1}$. Temperature control is reached with Peltier elements allowing fast heating and cooling of the aluminium body of the device. A detailed description of this device may be obtained from P. Gross (INRA, Nancy Research Centre, Champenoux, France; Gross@ nancy.inra.fr). Ground fluorescence of the treated leaf disk was monitored continuously in complete darkness with a PAM-2000 fluorometer (Heinz Walz, Effeltrich, Germany) with fiberoptics inserted into the aluminium body just over the leaf sample (red modulated light, PFD $<1 \mu \mathrm{mol} \mathrm{m} \mathrm{m}^{-2} \mathrm{~s}^{-1}$ ). $T_{c}$ was estimated graphically from the fluorescence traces. Mean values from four different leaves were computed and compared by a repeated measurement ANOVA and a Tukey post-hoc test at $P<0.05$.

\section{RESULTS}

Maximal quantum yield of dark adapted leaves $\left(F_{v} / F_{m}\right)$ was around 0.81 in $Q$. suber and in $Q$. canariensis after a week at $15{ }^{\circ} \mathrm{C} . F_{v} / F_{m}$ remained stable despite the increase of ambient temperature up to $35^{\circ} \mathrm{C}$ and declined slightly after returning to $15^{\circ} \mathrm{C}$, the decline being larger in $Q$. canariensis where a mean value of 0.76 was reached (Fig. 1).

The actual quantum yield of photochemistry $\left(\Delta F / F_{m}\right)$ showed a clear rise with temperature with a maximum between 25 and $35^{\circ} \mathrm{C}$ and a decrease above this optimum. These temperature response curves were affected by ambient temperatures and showed a visible shift of $T_{\text {opt }}$ towards higher temperatures (Fig. 2). Adjusting the temperature response function 


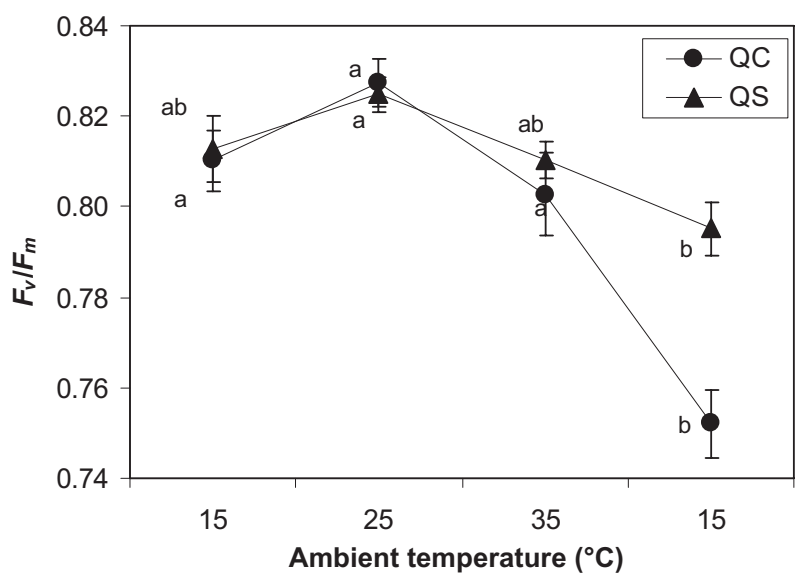

Figure 1. Effects of ambient temperature on the maximal quantum yield of photochemistry $\left(F_{v} / F_{m}\right)$ in leaves of Quercus suber (QS) and $Q$. canariensis $(\mathrm{QC})$. The ambient temperature sequence (5 days at each step) was $15,25,35$ and back to $15^{\circ} \mathrm{C}$ as shown by the lines between the individual points. Different letters indicate significant differences at $p<0.05$ within a given species.

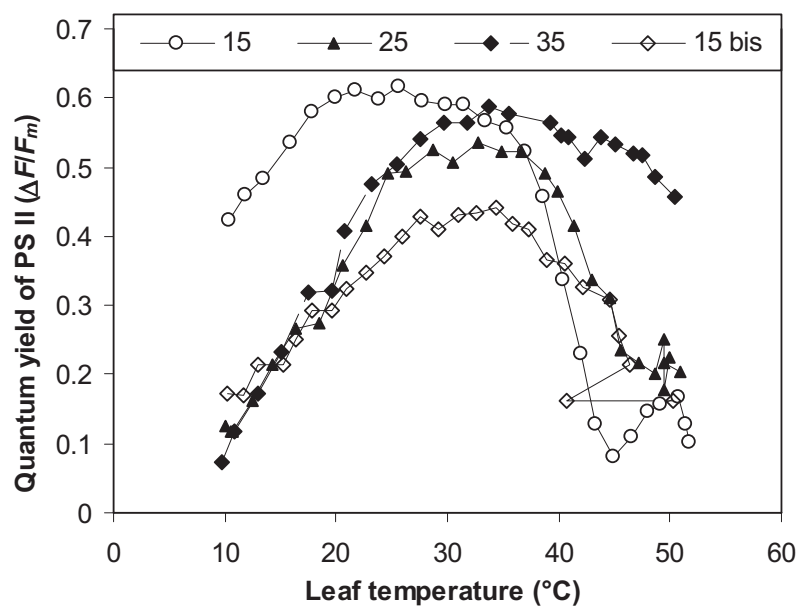

Figure 2. Examples of temperature response of PS II quantum yield measured by chlorophyll a fluorescence $\left(\Delta F / F_{m}\right)$ under $1000 \mathrm{ppm}$ $\mathrm{CO}_{2}, 1 \% \mathrm{O}_{2}$ and a PFD of $500 \mathrm{mmol} \mathrm{m}^{-2} \mathrm{~s}^{-1}$ with leaves of $Q . c a$ nariensis that were acclimated during 5 days to an ambient temperature of $15,25,35$ and back to $15{ }^{\circ} \mathrm{C}$ (the latter referred to as 15 bis in the legend). The response curves were used to estimate $T_{o p t}$, the optimal temperature for light-driven electron flow with Equation (1). See text for details.

(Eq. (1)) to these responses yielded the estimates of $T_{o p t}$ used in the following analyses.

$T_{\text {opt }}$ was 29.8 and 26.8 at $15{ }^{\circ} \mathrm{C}$ for $Q$. suber and $Q$. canariensis, respectively (Fig. 3A). $T_{\text {opt }}$ increased significantly when ambient temperature was increased to 25 and $35^{\circ} \mathrm{C}$, to a different extent in the two species. The enhancement was much larger in $Q$. suber $(+10.7)$ than in $Q$. canariensis $\left(+1.9^{\circ} \mathrm{C}\right)$. $T_{\text {opt }}$ went on rising in $Q$. canariensis during reacclimation to $15^{\circ} \mathrm{C}$, while it decreased rapidly in $Q$. suber. The reversibility of the increase was not complete and $T_{\text {opt }}$ remained largely
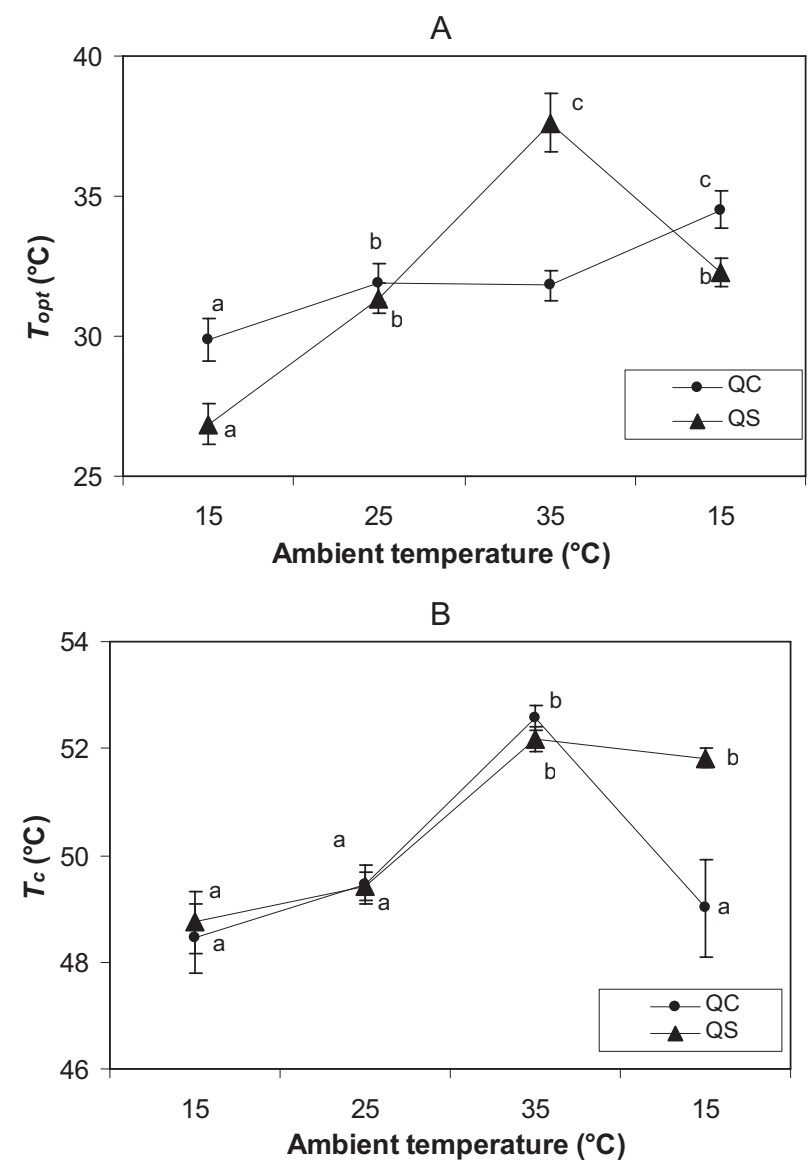

Figure 3. Effects of ambient temperature on (A) the optimal temperature of photochemical efficiency $\left(T_{o p t}\right)$ and (B) the critical temperature for PS II stability $\left(T_{c}\right)$ of leaves of $Q$. suber (QS) and $Q$. $c a$ nariensis (QC). The ambient temperature sequence (5 days at each step) was $15,25,35$ and back to $15^{\circ} \mathrm{C}$ as shown by the lines between the individual points. Different letters indicate significant differences at $p<0.05$ within a given species.

above the initial values $\left(+5.4\right.$ and $4.6^{\circ} \mathrm{C}$ in $Q$. suber and $Q$. canariensis, respectively). $T_{c}$ was initially very close in the two species (around $48{ }^{\circ} \mathrm{C}$ at $15{ }^{\circ} \mathrm{C}$ ) and increased readily up to almost $52{ }^{\circ} \mathrm{C}$ at $35^{\circ} \mathrm{C}$ ambient temperature (Fig. 3B). The decrease upon returning to $15^{\circ} \mathrm{C}$ was stronger in $Q$. canariensis than in $Q$. suber. The correlation between the two values was very tight in the case of $Q$. suber, but not in $Q$. canariensis (Fig. 4).

A detailed comparison of $T_{c}$ among species (Fig. 5) revealed a large and significant effect of ambient temperature and a smaller one of species, with no interaction (Fig. 5). The temperature rise induced significant increases of $T_{c}$, while the return to $15{ }^{\circ} \mathrm{C}$ resulted in a significant decrease without full recovery of initial values. Among species, only $Q$. coccifera differed from $Q$. suber but not from the other species. Initial values of critical temperature at $15^{\circ} \mathrm{C}$ ambient temperature were comprised between $44.5^{\circ} \mathrm{C}$ and $49.8{ }^{\circ} \mathrm{C}$. At $35^{\circ} \mathrm{C}$, $T_{c}$ increased to $50.8-52.5^{\circ} \mathrm{C}$ with only small inter-specific 


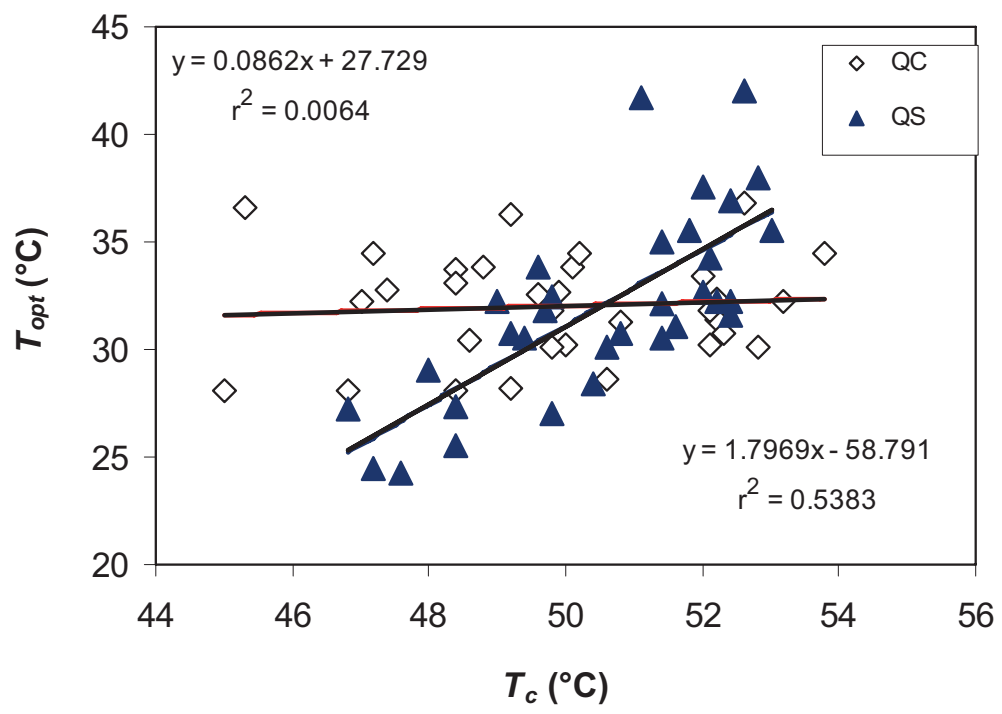

Figure 4. Correlation between critical temperature for PSII stability $\left(T_{c}\right)$ and optimal temperature for light driven electron flow $\left(T_{o p t}\right)$. Each point represents a paired measurement of $T_{o p t}$ and $T_{c}$ on a leaf and a disk from an adjacent leaf.

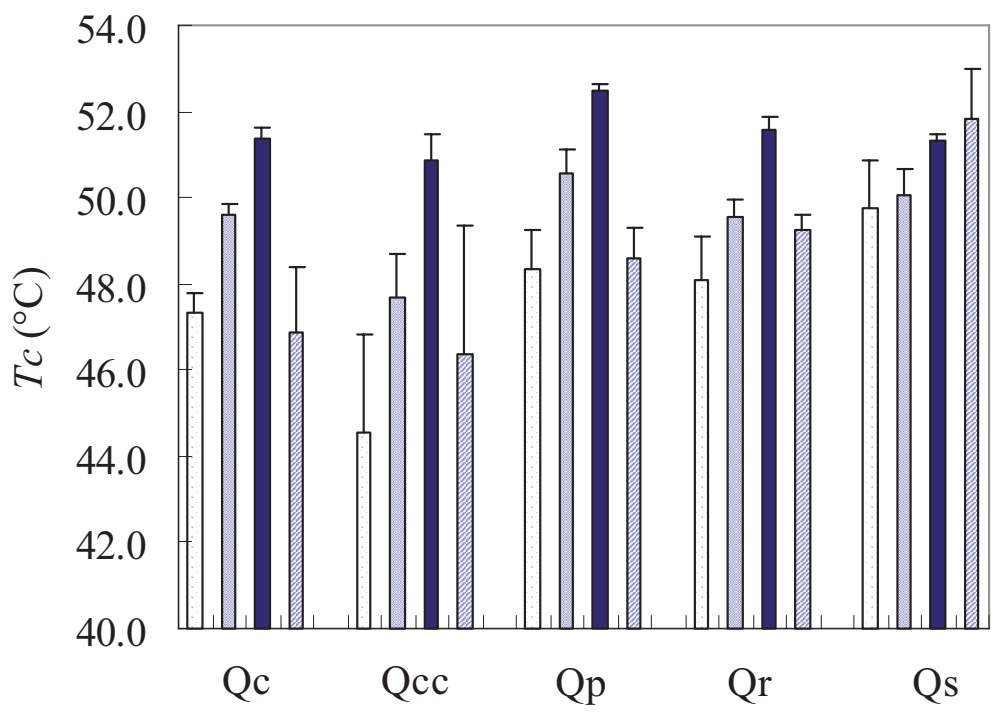

Figure 5. Effects of ambient temperature on the critical temperature for PS II stability $\left(T_{c}\right)$ of leaves of $Q$. suber (Qs), $Q$. canariensis (Qc), Q. robur $(\mathrm{Qr})$ Q. petraea $(\mathrm{Qp})$ and $Q$. coccifera $(\mathrm{Qcc})$ The ambient temperature sequence $\left(5\right.$ days at each step) was $15,25,35$ and back to $15{ }^{\circ} \mathrm{C}$ and resulting values of $T_{c}$ are presented sequentially. Means $\pm \mathrm{SE}, n=4$. Results from a repeated measurements ANOVA were: species effect, $F=5.67, p=0.0073$; temperature effect: $F=14.53, p<0.0001$; interaction: $F=1.28, p=0.270$. Species differences were small and a post hoc Tukey test produced a difference between $Q$ coccifera and $Q$. suber $(p=0.00759)$, and small differences between $Q$. coccifera and $Q$. petraea $(p=0.069)$ and between $Q$. canariensis and $Q$. suber $(p=0.0703)$. All other comparisons resulted in $p>0.01$. See Table I for detailed temperature effects.

differences. The recovery after return to $15{ }^{\circ} \mathrm{C}$ was very effective in all species except $Q$. suber.

\section{DISCUSSION}

The ambient temperatures imposed to the oaks saplings during this series of experiments $\left(\max 35{ }^{\circ} \mathrm{C}\right.$ under moderate irradiance) never induced a severe decay of the photo- synthetic apparatus, as shown by the almost complete stability of the maximal quantum yield of photochemistry $\left(F_{v} / F_{m}\right)$. The thermal treatments therefore mainly induced acclimation (Sharkey, 2005). Nevertheless, a temperature of $35^{\circ} \mathrm{C}$ was already at the threshold of damaging levels, as shown by the small decrease of $F_{v} / F_{m}$ between 25 and $35{ }^{\circ} \mathrm{C}$. Similar observations have been repeatedly reported. In $Q$. suber, $F_{v} / F_{m}$ declined when ambient temperature increased above $32{ }^{\circ} \mathrm{C}$ Ghouil et al. (2003). This was also the case at $35{ }^{\circ} \mathrm{C}$ in 
Table I. Effects of ambient temperature on the critical temperature for chlorophyll a fluorescence $\left(T_{c}\right)$ of leaves of $Q$. suber, $Q$. canariensis, $Q$. robur, $Q$. petraea and $Q$. coccifera: pairwise comparisons of $T_{c}$ at different acclimation temperatures with a Tukey post hoc test; probabilities are provided. Corresponding data in Figure 5.

\begin{tabular}{lccc}
\hline $\begin{array}{l}\text { Acclimation } \\
\text { temperature }\left({ }^{\circ} \mathrm{C}\right)\end{array}$ & 25 & 35 & Back to 15 \\
\hline 15 & $p=0.00848$ & $p=0.000166$ & $P=0.387$ \\
25 & & $p=0.0520$ & $P=0.296$ \\
35 & & & $P=0.000526$ \\
\hline
\end{tabular}

Acer pseudoplatanus, Betula pendula, Fagus sylvatica (Dreyer et al., 2001), in Abies alba (Robakowski et al., 2002) and in Cedrus atlantica and C. libani (Epron, 1997a). These decreases were mainly due to declining levels of maximal fluorescence $\left(F_{m}\right)$ that may reach $65 \%$ at $45{ }^{\circ} \mathrm{C}$ for $Q$. pubescens (as compared to a $10 \%$ reduction in $F_{0}$ ) (Haldimann and Feller, 2004). Such a decrease in $F_{m}$ is thought to result from of a reversible change of the thermal dissipation rate constant $K_{D}$ due to conformational changes in PSII allowing increased thermal energy dissipation (Yamane et al., 1997). Interestingly, when ambient temperature was returned to the initial level of $15^{\circ} \mathrm{C}, F_{v} / F_{m}$ not only showed no sign of recovery, but even decreased further in the case of $Q$. canariensis. Such persistent after-effect of high ambient temperature remain poorly understood (Sharkey, 2005).

Severe damage to photosystems occurs only at much higher temperature, and is usually evidenced by a steep increase of ground fluorescence $F_{0}$. In Arbutus unedo, such increases occurred above $47{ }^{\circ} \mathrm{C}$ (Schreiber and Berry, 1977). Similarly, $F_{0}$ was found to remain stable from 25 up to $45^{\circ} \mathrm{C}$ in $Q$. pubescens, revealing a stability of the thylakoid membrane of PSII reaction centres till rather high temperatures (Haldimann and Feller, 2004). The increase of $F_{0}$ at high temperatures may be interpreted as a decrease of $K_{P}$, rate constant for photochemistry, due to fluidification of thylakoid membranes or to less efficient connections between light harvesting antenna and core reaction centres (Ducruet et al., 2007; Yamane et al., 1997).

$T_{c}$ is known to be highly plastic. Increased $T_{c}$ in response to rising temperature and to drought is a common occurrence in a many species. The largest acclimation described in the literature was recorded in $Q$. suber: $T_{c}$ increased from 42 to $51{ }^{\circ} \mathrm{C}$ under drought at stable ambient temperatures (Ghouil et al., 2003). An almost similar increase was recorded when ambient temperatures increased from 15 to $35^{\circ} \mathrm{C}$. The increase observed in the five oak species was of smaller amplitude; this was due solely to the fact that initial values at $15^{\circ} \mathrm{C}$ were larger in the present experiment while the highest levels under $35^{\circ} \mathrm{C}$ ambient temperature were very similar (around $52{ }^{\circ} \mathrm{C}$ ). This apparent discrepancy can be due to the fact that the saplings used by Ghouil et al. (2003) had been grown at low temperature before the measurements, while in the present case the saplings had already been submitted to summer temperatures as the measurements were made during October. This illustrates the plasticity of $T_{c}$, and the fact that minimal values of $T_{c}$ are only reached after long time at low temperatures, possibly with young leaves. This opens the question of the reversibility of the acclimation of $T_{c}$ to high temperatures, which remains much less documented.

We found a large variability in the decrease of $T_{c}$ after returning the saplings to $15^{\circ} \mathrm{C}$. In a majority of the tested species, returning to $15{ }^{\circ} \mathrm{C}$ resulted in a decrease of $T_{c}$ down to values close to, but still slightly above the initial values. The decline of $T_{c}$ was therefore almost of the same extent than the increase observed during the two preceding weeks. Only $Q$. suber did not display any down regulation after returning to $15^{\circ} \mathrm{C}$. To our knowledge, there are only few experimental data available on the reversibility of acclimation of $T_{c}$ to high temperatures, and it is therefore still difficult to produce a clear conclusion about the general characteristics of the deacclimation process.

Inter-specific differences of $T_{c}$ were small, as well for the absolute values as for the degree of plasticity. Moreover, small differences were detected before the high temperature treatment, while all species reached values close to $52{ }^{\circ} \mathrm{C}$ after the treatment and a few days at $15^{\circ} \mathrm{C}$ resulted in almost full recovery of the initial low levels. Only $Q$. suber behaved abnormally as compared to the four other species, and there was no obvious reason for this.

The increase of $T_{c}$ was clearly paralleled by an increase in the optimal temperature for electron flow $\left(T_{\text {opt }}\right)$. $T_{\text {opt }}$ was as expected much smaller than $T_{c}$, and close to $26-30{ }^{\circ} \mathrm{C}$ in saplings at $15{ }^{\circ} \mathrm{C}$. It increased to $35^{\circ} \mathrm{C}$ in $Q$. suber and to lower values in $Q$. canariensis in response to moderate heat. In this latter species $T_{o p t}$ increased after returning to $15{ }^{\circ} \mathrm{C}$, which could mean that the low values at $35^{\circ} \mathrm{C}$ were an artefact. A direct comparison of $T_{c}$ and $T_{\text {opt }}$ revealed a relatively tight correlation in $Q$ suber: acclimation of $T_{c}$ to increased ambient temperature has visible consequences for the optimal temperature for light-driven electron transfer. Such was not the case in $Q$. canariensis, for a reason that remains to be investigated.

A close link between the plastic responses of $T_{c}$ and $T_{o p t}$ has important practical consequences, as $T_{c}$ is very easy to record with automated procedures, while $T_{\text {opt }}$ requires the use of a gas exchange chamber, calibrated gas mixtures and standardised conditions that make a large scale survey among species and genotypes time-consuming and unreliable. A new version of the measurement device developed in our laboratory can simultaneously process six leaf samples, and allows repetitions and quantitative analyses of diversity.

\section{CONCLUSION}

(1) All tested oak species displayed a large plasticity of the critical temperature for photochemistry $\left(T_{c}\right)$ with increasing ambient temperatures; the geographic origin of the species had no visible consequence for this plasticity, nor for the maximal value of $T_{c}$.

(2) The increase of $T_{c}$ was reversible in all tested oak species (with the notable exception of $Q$. suber); this rapid reversion lead to a return to close-to-initial values. 
(3) Increases in $T_{c}$ were to some extent paralleled by changes in optimal temperature for electron transfer; the low number of available data allowed no clear conclusion about the respective amplitude of the changes; but the observed changes clearly show that changes in thermostability of reaction centres are not occurring independently of changes in the electron transport chain, and may be used as an index for an acclimation of the whole photosynthetic apparatus.

Acknowledgements: This research was part of a cooperative research program supported by the French Ministry for Foreign Affairs (CMCU project "Regeneration of Cork Oak in Tunisia"). The important contributions of Jean Marie Gioria in growing the saplings, and of Patrick Gross in building the device for critical temperature estimation, are gratefully acknowledged. The continuous support of $\mathrm{M}$ Ksontini and M Rejeb (INRGREF, Tunis) to C Daas and this project was very helpful.

\section{REFERENCES}

Berry J., Björkman O., 1980. Photosynthetic response and adaptation to temperature in higher plants. Ann. Rev. Plant Physiol. 31: 491-543.

Bilger H.W., Schreiber U., Lange O.L., 1984. Determination of leaf heat resistance: comparative investigation of chlorophyll fluorescence changes and tissue necrosis methods. Oecologia 63: 256-262.

Cajanek M., Stroch M., Lachetovri I., Kalina J., Spunda V., 1998. Characterization of the photosystem II inactivation of heat-stressed barley leaves as monitored by the various parameters of chlorophyll a fluorescence and delayed fluorescence. J. Photobiol. B: Biol. 47: $39-45$.

Dreyer E., Le Roux X., Montpied P., Daudet F.A., Masson F., 2001. Temperature response of leaf photosynthetic capacity in seedlings from seven temperate tree species. Tree Physiol. 21: 223-232.

Ducruet J.M., Peeva V., Havaux M., 2007. Chlorophyll thermofluorescence and thermoluminescence as complementary tools for the study of temperature stress in plants. Photosyn. Res. 93: 159-171.

Epron D., 1997a. Effects of drought on photosynthesis and on the thermotolerance of photosystem II in seedlings of cedar (Cedrus atlantica and C. libani). J. Exp. Bot. 48: 1835-1841.

Epron D., 1997b. The temperature dependance of photoinhibition in leaves of Phaseolus vulgaris L. Influence of $\mathrm{CO}_{2}$ and $\mathrm{O}_{2}$ concentrations. Plant Sci. 124: 1-8.

Froux F., Ducrey M., Epron D., Dreyer E., 2004. Seasonal variations and acclimation potential of the thermostability of photochemistry in four Mediterranean conifers. Ann. For. Sci. 61: 235-241.

Genty B., Briantais J.M., Baker N.R., 1989. The relationship between the quantum yield of photosynthetic electron transport and quenching of chlorophyll fluorescence. Biochim. Biophys. Acta. 990: 87-92.

Ghouil H., Montpied P., Epron D., Ksontini M., Hanchi B., Dreyer E., 2003. Thermal optima of photosynthetic functions and thermostability of photochemistry in cork oak seedlings. Tree Physiol. 23: 10311039.

Haldimann P., Feller U., 2004. Inhibition of photosynthesis by high temperature in oak (Quercus pubescens L.) leaves grown under natural conditions closely correlates with a reversible heat-dependent reduction of the activation state of ribulose-1,5-bisphosphate carboxylase/oxygenase. Plant Cell Environ. 27: 1169-1183.

Havaux M., 1992. Stress tolerance of photosystem II in vivo. Antagonistic effects of water, heat and photoinhibition stresses. Plant Physiol. 100: $424-432$.
Havaux M., 1993. Rapid photosynthetic adaptation to heat stress triggered in potato leaves by moderately elevated temperatures. Plant Cell Environ. 16: 461-467.

Hüve K., Bichele I., Tobias M., Niinemets Ü., 2006. Heat sensitivity of photosynthetic electron transport varies during the day due to changes in sugars and osmotic potential. Plant Cell Environ. 29: 212228.

Ivanov A.G., Kitcheva M.I., Christov A.M., Popova L.P. 1992. Effects of abscissic acid treatment on the thermostability of the photosynthetic apparatus in barleys chloroplasts. Plant Physiol. 98: 1228-1232.

June T., Evans J.R., Farquhar G.D., 2004. A simple new equation for the reversible temperature dependence of photosynthetic electron transport: a study on soybean leaf. Funct. Plant Biol. 31: 275-283.

Kitajima H., Butler W.L., 1975. Quenching of chlorophyll fluorescence and primary photochemistry in chloroplasts by dibromothymoquinone. Biochim. Biophys. Acta 376: 105-115.

Knight C.A., Ackerly D.D., 2002. An ecological and evolutionary analysis of photosynthetic thermotolerance using the temperaturedependent increase in fluorescence. Oecologia. 130: 505-514.

Ladjal M., Epron D., Ducrey M., 2000. Effects of drought preconditioning on thermotolerance of photosystem II and susceptibility of photosynthesis to heat stress in cedar seedlings. Tree Physiol. 20: 1235-1241.

Medlyn B.E., Dreyer E., Ellsworth D., Forstreuter M., Harley P.C., Kirschbaum M.U.F., Le Roux X., Loustau D., Montpied P., Strassemeyer J., Walcroft A., Wang K., 2002a. Temperature response of parameters of a biochemically based model of photosynthesis. II A review of experimental data. Plant Cell Environ. 25: 1167-1179.

Medlyn B.E., Loustau D., Delzon S. 2002b. Temperature response of parameters of a biochemically based model of photosynthesis. I. Seasonal changes in mature maritime pine (Pinus pinaster Ait.). Plant Cell Environ. 25: 1155-1165.

Rennenberg H., Loreto F., Polle A., Brilli F., Fares S., Beniwal R.S., Gessler A., 2006. Physiological responses of forest trees to heat and drought. Plant Biol. 8: 556-571.

Robakowski P., Montpied P., Dreyer E., 2002. Temperature response of photosynthesis in silver fir (Abies alba) seedlings. Ann. For. Sci. 59: $163-170$.

Salvucci M.E., Crafts-Brandner S.J., 2004. Relationship between the heat tolerance of photosynthesis and the thermal stability of rubisco activase in plants from contrasting thermal environments. Plant Physiol. 134: 1460-1470.

Schreiber U., Berry J.A., 1977. Heat-induced changes of chlorophyll fluorescence in intact leaves correlated with damage of the photosynthetic apparatus. Planta 136: 223-238.

Sharkey T.D., 2005. Effects of moderate heat stress on photosynthesis: importance of thylakoid reactions, rubisco deactivation, reactive oxygen species, and thermotolerance provided by isoprene. Plant Cell Environ. 28: 269-277.

Terzaghi W.B., Fork D.C., Berry J.A., Field C.B., 1989. Low and high temperature limits to PSII. A survey using trans-parinaric acid, delayed light emission, and $F_{o}$ chlorophyll fluorescence. Plant Physiol. 91: 1494-1500.

Yamane Y., Kashino Y., Koike H., Satoh K., 1997. Increase in the fluorescence $F_{o}$ level and reversible inhibition of Photosytem II reaction centre by high temperature treatments in higher plants. Photosyn. Res. 52: 57-64.

Yamori W., Noguchi K.O., Terashima I., 2005. Temperature acclimation of photosynthesis in spinach leaves: analyses of photosynthetic components and temperature dependencies of photosynthetic partial reactions. Plant Cell Environ. 28: 536-547.

Yordanov I., 1992. Response of photosynthetic apparatus to temperature stress and molecular mechanisms of its adaptation. Photosynthetica 26: 517-531. 